\title{
Enhancing Work Performance of Extension Agents among Cocoa Farmers in Malaysia: The Influence of Human Resource Development Skills
}

\author{
Oluwatoyin OLAGUNJU' ${ }^{1, *}$, Salim HASSAN ${ }^{2}$, \\ Mohd Yusoff Abd SAMAD ${ }^{3}$ and Ramle KASIN ${ }^{4}$
}

\author{
${ }^{1}$ Department of Agricultural Economics and Extension, Faculty of Agriculture, \\ Adekunle Ajasin University, Akungba-Akoko, Nigeria \\ ${ }^{2}$ Department of Agriculture Technology, Faculty of Agriculture, Universiti Putra Malaysia, Malaysia \\ ${ }^{3}$ Department of Land Management, Faculty of Agriculture, Universiti Putra Malaysia, Malaysia \\ ${ }^{4}$ Malaysian Cocoa Board, Sabah, Malaysia
}

("Corresponding author email: toyinolagunju01@gmail.com)

Received: 26 September 2019, Revised: 15 May 2020, Accepted: 10 June 2020

\begin{abstract}
This study examines the relationships between human resource development skills (leadership, decision making support, and social skills) with the work performance of extension agents among cocoa farmers in Malaysia. The study used stratified sampling technique to select 668 cocoa farmers who were exposed to extension programs facilitated by extension agents of the Malaysian Cocoa Board in 3 regions of Malaysia. The data were analyzed using descriptive statistics, correlation, and regression analyses. The results show that cocoa farmers rated level of work performance, leadership, decision making support, and social skills as high. Significant and positive correlation $(p<0.01)$ existed between each variable and work performance. Regression analysis results showed that leadership skill, decision making support skill, and social skill were significant predictors to enhance work performance. The $R^{2}$ value of 0.564 indicates that the 3 skills gave $56.4 \%$ explanation of the variance in extension agents' work performance. The results also suggested that decision making support skill $(\beta=0.321)$ was the most important factor that influenced work performance, followed by leadership skill and social skill. Hence, decision making support skill, leadership skill, and social skill should be taken into consideration in enhancing work performance, especially among farmers and the extension agents who work with them, for continuous performance improvement in their work. The skills that have been identified in this study can be integrated into both the pre-service and in-service training and development of extension agents in their line of work to improve their skills in sharing new technology.
\end{abstract}

Keywords: Cocoa farmers, Extension agents, Human resource development, Skills, Work performance

\section{Introduction}

Malaysia is among the top cocoa grinding countries, falling into the fifth position globally, and also occupies the number 1 position in the whole continent of Asia [1]. Presently, the local cocoa production capacity has reduced drastically to the extent that the grinding sector is unsustainable, and this has resulted in an imbalance between the upstream and the downstream sectors [2,3]. However, the development of cocoa upstream activities is not keeping pace with the downstream industry, by depending on imported cocoa beans to meet the needs of the processing industry [4]. This situation has arisen as cocoa has become the least favorable crop among farmers; due to factors such as the price of cocoa beans, pests and diseases, and labor constraints [5], both the plantation sector and smallholders 
have decided to abandon cocoa production for other more profitable crops like oil palm, rubber, and pepper [6]. This setback has resulted in a yearly decline of cocoa production in the country [7]. To resolve the problem identified, extension programs were introduced by the Malaysian Cocoa Board (MCB) in order to transfer technology, as regards materials and knowledge, to increase production of cocoa beans in the country. MCB extension agents are responsible for transferring cocoa technology to the farmers; their roles are to facilitate programs involving, as well as to disseminate information available on cocoa technology to, farmers. Although MCB extension agents have been doing the work of technology transference to cocoa farmers, there has not been obvious improvement in their performance as far as cocoa production is concerned. According to [8], for extension agents to achieve meaningful results in any programs or transferred technology, they should be carried out with the required skills and knowledge that will enhance farmers' capabilities and potentials towards increasing production.

Conversely, extension agents' low performance in human resource development has been attributed to problems of poor skills and inadequacies in the professional competencies needed to skillfully perform the work assigned to them [9]. It is not common in research to identify the specific skills that the extension agents need to perform the duties assigned to them and how they are to utilize them to promote rural and agricultural development towards increased agricultural productivity [10]. Such studies are scarce in agricultural extension, especially with regards to issues such as work performance and human resource development. To achieve sustainable improvement in cocoa production, there is a need for extension agents to develop the level of skills and knowledge required in human resource development for effective technology transfer and its process of dissemination to cocoa farmers. Many studies have been conducted to assess core competencies considered to be useful by extension agents in agricultural extension education and service delivery in the areas of non-technical and process skills, such as technical competence, communication abilities, interpersonal relations, demonstration methods, critical and thinking ability to interpret program impacts, teamwork, and human resource development activities. It was found that, if extension agents possessed these competencies, it would enhance their effectiveness in the discharge of their duties [10-14].

However, these studies have not linked extension agents' human resource development skills to work performance. Furthermore, limited studies have been conducted that have placed an emphasis on the human resource development competencies needed by extension agents for personal and clients' development for improved performance $[15,16]$. Although similar studies were conducted in Ethiopia [17], Nigeria [18] and Tanzania [19], they cannot be used for generalization, due to different crops, geographical location, culture, and needs. Also, previous studies in Malaysia focused more on extension agents' assessment of work performance in an open context, as it is related to good agricultural practice, and not from the perspective of farmers' assessment. The studies failed to recognize the impact of farmers and their roles in influencing work performance of the extension agents in the course of technology transfer and adoption.

This study would generate important knowledge in the field of human resource development for agricultural extension service delivery across the world, especially from extension agents of the MCB, to be used as a reference and for future research. Practically, transferring technology to farmers by competent and skillful extension agents is very important for an improved standard of living and productivity. Additionally, the results and findings of this study would be used as the basis for involvement in transforming extension workers into effective change agents. It would unveil the realistic prospect of professionalism through human resource development skills in extension agents that could be used to effect attitudinal change amongst farmers to be responsive to new technology and participate actively in agricultural development [13].

Identifying skills that contribute to the work performance of extension agents could be integrated into MCB extension activities and the transfer of technology programs. By so doing, extension agents would have the opportunity to attain the required skills necessary for their successive performance. Furthermore, revealing the important skills could be used for training frontline extension personnel officers, and could also be used to ensure that application of those skills would enhance their performances and establish effective working relationships with cocoa farmers, as this may be important in determining their performances [20]. By acknowledging the importance of HRD skills on workers 
performance, this paper studies the association of HRD skills (specifically on leadership skill, decision making support skill, and social skill) with work performance, with the aim that this study can assist extension agencies and the MCB to better understand how human resource development influences work performance. Additionally, the research findings will also contribute knowledge to the examined agencies by developing extension agent capability towards bringing work performance into proper or desirable coordination with the standards set by the management.

Realizing the importance of extension agents' acquired skills in technical areas, to transfer cocoa technology to farmers, and in human areas, to develop farmers' capacity and potential to be able to adopt and practice the technology disseminated to them, this study addresses the following relevant questions: What is the level of human resource development skills and work performance of extension agents, as perceived by cocoa growers? Are there significant relationships between selected HRD skills and work performance? What are the factors contributing to extension agents' work performance, as perceived by cocoa growers? Thus, this study was carried out to determine the influence of human resource development skills on extension agents' work performance among cocoa farmers in Malaysia. Specifically, the objectives to be achieved are as follows:

1. To examine the level of human resource development skills and extension agents' work performance among cocoa farmers in Malaysia.

2. To determine the relationships between human resource development skills and extension agents' work performance among cocoa farmers in Malaysia.

3. To identify the most important human resource development skills that contribute to the work performance of extension agents among cocoa farmers in Malaysia.

\section{Research framework}

The research framework, as proposed in Figure 1, is composed of the independent variable (HRD skills) and the dependent variable (work performance). A direct relationship exists between HRD skills and work performance. Based on the proposition of Human Capital Theory (HCT), levels of productivity (i.e., work performance) are influenced by HRD skills [10,12,14,21]. In line with the proposition of HCT, the research framework suggests that HRD skills such as leadership skill, decision making support skill, and social skill primarily influence the level of work performance.

Independent variable

Dependent variable

\begin{tabular}{|ll|}
\hline & \multicolumn{1}{c|}{ HRD skills } \\
o & Leadership skill \\
o & Decision making support skill \\
o & Social skill \\
\cline { 2 - 2 }
\end{tabular}

Work performance

Figure 1 Research framework of the relationship between HRD skills and work performance.

\section{Theoretical background}

Human capital theory (HCT) was used in this study as the basis for research framework design. Research has revealed that skills and knowledge have a lot of influence on work performance. The theory of human capital, introduced by [22], asserts that work performance is determined by investing in human capital that leads to human capital outcomes $[22,23]$. The conclusion was reached that, if individual employees in a particular organization acquire functional skills and knowledge, there would be increase in human abilities, which will serve as a reflection of future success possibility in individual and organizational performance. According to [22], investments in human capital improve the abilities of the people physically and mentally and, hence, increase their work performance potential. In general, the 
components that are of great significance or value in human capital development were emphasized, namely, education and training. Their importance can be very obvious, such that employees that have more education and training have the prospect of performing better than employees who do not.

By conceiving human capital as a form of outcomes that is produced as the final consequence of investments, [23] was of the opinion that it can also be conceptualized as a form of human capital that is duty and non-duty related. Duty-relatedness expresses that an investment in human capital and outcomes are specifically related to specific tasks such as developing farmers' capabilities [23]. In agricultural extension, human capital-related duty is associated with the activities of human resource development such as leadership experience, decision making experience, interpersonal relationships, and clients experience [24]. They see human capital theory as the totality of knowledge and skills acquired by individuals in relation to the process of education and training from other walks of life that will bring improvement to the quality of work performed [25].

Applying this theory to the study, education and training is an investment in general human capital needed by employees for enhanced performance in their duty [26]. Empirical evidence points out that specific human capital investment in human resource development which comprises leadership skill, decision making support skill, and social skill has greater impact on the work performance of extension agents [27]. This suggests that human resource development skills are paramount to the performance of individual employees in agricultural extension agencies. Hence, this study was aimed at investigating how human resource development skills influence the work performance of extension agents (Figure 2).

\section{Hypotheses development}

This study tested the following hypotheses:

H1: Leadership skill will influence extension agents' work performance.

H2: Decision making support skill will influence extension agents' work performance.

H3: Social skill will influence extension agents' work performance.

H4: Leadership skill, decision making support skill, and social skill act together to influence work performance.

\section{Extension agents' work performance}

Agricultural extension agents have been described as being remarkable in having the potential to transfer and facilitate the knowledge, skills, and technologies needed to support and inspire farmers to have better production and income [28]. It was confirmed by [29] that agricultural extension systems have different results when their impacts and performances are put into consideration. [30] earlier revealed that the economic and social impacts of extension programs in some countries are very high, while the ways and processes used in delivering extension systems in most of the developing countries has, over time, not been effective in meeting different technological challenges demanded by farmers and people living in rural areas. Consequently, extension activities having effective delivery that will lead to improved performance depends on how extension agents utilize the knowledge they have, along with required skills and expertise. By paying particular attention to this, the performance of individual workers is, to a great extent, very important to bring about the expected results, which are based on the acquired knowledge and skills which have a lot of influence on them [31]. The individual performances of employees in an organization are purely dependent on the policies based on the abilities, knowledge, and skills acquired from organizational tasks which are considered as important factors to enhance the productivity and output that is needed to sustain their effective performances and the responses of clients [32].

\section{Leadership skill and work performance}

The concept of leadership, as it is related to agricultural extension, calls for action, and is strategically important since it has to do with influencing and developing groups of farmers in the community; extension agents can be seen as people who have leadership capabilities to bring innovation, change, and development, not only to the farmers, but also to the resources within the community [33]. At this point in time, the similarity between extension agents' leadership roles and farmers demands the 
display of relevant skills to carry out their functions among diverse groups of rural dwellers [34]. The importance of leadership skills has been generally agreed upon to explain both employee and organizational performance in different employment sectors [35]. The ability of extension agents to display leadership competence determines to a great extent the success of an extension services organization. Extension workers should have understanding of the importance of farmers in achieving the goals of the extension services, while motivation and encouragement of those farmers will be very crucial to achieving the organization goals. It is commonly accepted that, for any organization to be effective, there is a need for effective leadership; neglect of this aspect will lead to poor performance of the organization [36,37]. In addition, it is broadly acknowledged that, for an individual to be effective, leadership quality and approach is a determinant. The behavior exhibit by a leader will positively affect outcomes in terms of effectiveness and efficiency, which may affect effective performance [38].

\section{H1: Extension agents' leadership skill will influence their work performance.}

\section{Decision making support skill and work performance}

Workers are employed by their employers to be able to solve problems and make effective decisions when the need arises, but employees often do not have skills that meet employers' expectations $[39,40]$ stated that decisions involve the result of a composite social process that cannot just be an easy and unitary event but takes a longer period of time. They stated that taking decisions can be characterized by active factors that begin with identifying the motivation for action, and end with an interest in taking a specific action of commitment. Kalita [41] defined a decision as a continuing process of weighing different options attached to a particular goal, which usually comes about if there is an available solution to be implemented. On the other hand, [41] defined decision making as the process of recognizing and making a selection from a number of alternative solutions to a problem based on the available situation. Moreover, understanding decision making skills is of great significance, as it is evidence in research that good decision-making skills are related to superior performance [39]. Nevertheless, they emphasized the importance of identifying such decision-making skill by arguing that, to know why an organization is doing what they are doing and why they are performing in the way they are, those who represent the decision makers and the skills they have should be studied. Furthermore, results of studies conducted by [40-42] indicated that, for extension agents to maintain favorable decision-making patterns that will lead to work performance, there is a need for more training. Finally, maximum effects would likely occur, as this study will suggest that decision making skills are indeed able to bring change in the ability of the extension agents and farmers and enhance work performance.

H2: Extension agents' decision-making support skill will influence their work performance.

\section{Social skill and work performance}

A great part of different occupations involves the use of social skill, which may be in terms of working with the public, coworkers, or a particular set of clients. Social skills have always been important in the work place, as individuals require raising their frequency of skillful interactions with others in order to accomplish their tasks [43]. Hochwarter et al. [44] revealed that social skill has been very important to organizations, in that they are now using more team-based arrangements, as well as employing more service-oriented jobs. Generally, it was reported that people with strong social skill have high performance ratings, having experienced positive social interactions with people [45]. Lately, a theory was constructed about social skill being a moderator that enhances peoples' performance [46]. Okumura and Usui [47] confirmed that social skill moderated the association that exists between conscientiousness and work performance, such that the correlation was stronger for individuals with higher social skill. In the research conducted by [16], the results of the study showed high positive correlation between social skill abilities of extension agents and their performance by pointing out that, among all individual variables, social skill is the strongest contributor in explaining extension agents' performance.

H3: Extension agents' social skill will influence their work performance. 


\section{Human resource development and work performance}

Human resource development is the process of the development and/or unleashing of the expertise in employees through training and development, with the aim of improving process, individual, and organizational performance [48]. The end product of every human resource development effort is to improve individual employee performance, through programs planned and put into practice to improve their capacity or competence for effective performance [49]. Human resource development is designed purposely to enable individual employees to make every effort in achieving their goals. Also, previous researchers suggested that, if there are no capable employees that have such qualities like skills, knowledge, and experience to enable the achievement of positive results, to attain the goals of the organization becomes an illusion [50]. However, several studies have examined the connection between HRD and work performance. Studies conducted [51] established that HRD is correlated to performance, and also revealed that human capital investment has a significant positive impact on employees' performance. Also, the findings of the study carried out by [52] established that HRD practices are related to worker attitude, behavior, and performance. Furthermore, Hamid [53] researched the impact of HRD and organizational performance and revealed that the practices of developing employees led to a higher level of organizational and workers' performance. Human resource development, as conceptualized by the different researchers above, means that the present level of workers in an organization, in the area of skills and knowledge, can be increased through capacity building to a high level, for the purpose of achieving enhanced performance of the organizational workforce [50].

H4: Leadership skill, decision making support skill, and social skill act together to influence work performance.

\section{Materials and methods}

The sample for this study consisted of productive cocoa farmers who were exposed to extension activities facilitated by the extension agents of the Malaysian Cocoa Board in the 3 regions of Peninsular Malaysia, Sabah, and Sarawak, with 9 management location offices [54]. There are a total of 1,902 productive cocoa farmers in Malaysia. Therefore, the population for the study was 1,902 productive cocoa farmers that covered the 3 regions of Malaysia. In this study, the method of [55] was followed, at a reliability of 0.95 , along with a margin of error of 0.5 , to determine the sample size for research. The sample size formula is as follows;

$$
\mathrm{S}=\frac{\mathrm{X}^{2} \mathrm{NP}(1-\mathrm{P})}{\mathrm{d}^{2}(\mathrm{~N}-1)+\mathrm{X}^{2} \mathrm{P}(1-\mathrm{P})}
$$

where;

$\mathrm{S}=$ sample size required

$\mathrm{X}^{2}=$ chi squared table value for $1 \mathrm{~d} . \mathrm{f}$ (degree of freedom) at the confidence level as desired (3.841)

$\mathrm{N}=$ population size

$\mathrm{P}=$ proportion of population (for attaining maximum sample size, this was assumed to be 0.05 )

$\mathrm{d}^{2}=$ degree of accuracy expressed in proportion $(0.05)$

$$
\begin{aligned}
\mathrm{S} & =\frac{1.96^{2}(1,902) \times(0.5)(0.5)}{(0.05)^{2}(1,902)+1.96^{2}(0.5)(0.5)} \\
& =\frac{3.84 \times 1,902 \times 0.25}{0.0025 \times 1,902+3.84 \times 0.25} \\
& =\frac{1.825 .92}{5.715} \\
& =319.50 \quad=320
\end{aligned}
$$


A sample size of 1,122 far exceeds the minimum required for the 1,902 population, according to [55]. Note, however, the very uneven quantities in each variable, population, and research coverage required a large sample size for greater reliability, adequate and wide representation, the inclusion of people with different backgrounds, and statistical inferences. Furthermore, from the 3 locations of the study, Peninsular Malaysia and Sarawak have far smaller populations than Sabah and, by definition; they are not of the same proportion. Based on the table of Krejcie and Morgan, a representative sample of 1,902 is 1,122 , which was arrived by obtaining a representative size independently from the table for each MCB Management location office to adequately represent their populations. It is, therefore, crucial to justify the sample size to carefully and quantitatively describe the respondents and the population. Thus, descriptive, bivariate correlation and multiple regression were used to analyze the data to determine the level of human resource development skills and work performance, relationships between human resource development skills and work performance and the most important factor contributing to work performance. It is to be noted that a total of 1,122 questionnaires were distributed across the nine location offices within the 3 regions, but the number of accomplished returns was 671 respondents. However, during the data analysis, 668 responses were duly answered, as well as having complete valid cases, representing $60 \%$, and this indicates a good response. This is in line with [56], who reported a review of published social research literature and suggested that a $50 \%$ response rate is considered adequate for analysis and reporting, while a response of $60 \%$ is good and acceptable for analysis. Thus, the sample used for the analysis comprised 668 respondents.

The study used stratified sampling technique to meet the 668 respondents from 9 cocoa management locations in Malaysia, and this was carried out by using a well-structured 6-point scale questionnaire that was reviewed and pre-tested for validity and reliability. Moreover, in order to assess the responses of the farmers, a 6-point scale, ranging from strongly disagree to strongly agree, was used to measure all the variables, apart from their demographics and crop profiles. The 3-part questionnaire included: Demographics and crop profiles of respondents, human resource development with 3 dimensions (leadership skill, decision making support skill, and social skill), and work performance. The researcher employed IBM SPSS version 23 software for analyzing the data of this study. The questionnaire comprised measurement items on human resource development skills with 3 components: (a) leadership skill-containing 8 statement items; (b) decision making support skill-containing 7 statement items, and (c) social skill-containing 7 statement items, the last part of the questionnaire measured work performance of the extension agents. It also contained 8 statement items. The respondents were to indicate their perceptions based on the positive impact made on farmers by utilizing those skills through responses to all declarative statement items, which were rated on a 6-point scale and were scored with 6 points for Strongly Agree (SA), 5 points for Agree (A), 4 points for Somewhat Agree (SWA), 3 points for Somewhat Disagree (SWD), 2 point for Disagree (D), and 1 point for Strongly Disagree, as used by [16] and [57], and which were modified to suit the research purpose.

\section{Results and discussion}

\section{Farmers' demographic profiles}

The findings from the study, according to Table 1, indicated that $47.9 \%$ of the farmers were above 61 years old, which revealed that the highest numbers of the farmers involved in cocoa farming were older than 61 years of age. Out of 668 respondents, the study found that the majority were males, with 582 , equivalent to $87.1 \%$, with Malays $(33.8 \%$ ) being more involved in cocoa production than other races in Malaysia. More so, 334, equivalent to $50 \%$, realized less than RM1,000 in a month, and more than half of the respondents $(67.8 \%)$ undertook cocoa farming as a part time job. The descriptive analysis of educational level of the respondents indicated that $480(71.9 \%)$ had only completed primary education, $159(23.8 \%)$ had completed secondary education, and only $22(3.3 \%), 4(0.6 \%)$ and $3(0.4 \%)$ had a certificate, diploma, and bachelor/degree, respectively. 
Table 1 Farmers' demographic profiles.

\begin{tabular}{lcc}
\hline Variables & Frequency & Percentage \\
\hline Farmer's age & 16 & \\
$\leq 30$ & 50 & 2.4 \\
$31-40$ & 100 & 7.5 \\
$41-50$ & 182 & 15.0 \\
$51-60$ & 320 & 27.2 \\
$\geq 61$ & & 47.9 \\
Gender & 582 & \\
Male & 86 & 87.1 \\
Female & & 12.9 \\
Race & 226 & 33.8 \\
Malay & 62 & 9.3 \\
Chinese & 1 & 0.1 \\
Indian & 131 & 19.6 \\
Orange Asli & 126 & 18.9 \\
Kadazan & 16 & 2.4 \\
Murut & 1 & 0.1 \\
Bajau & 69 & 10.3 \\
Iban & 9 & 1.3 \\
Bidayuh & 27 & 4.0 \\
Others & & \\
Monthly income & 334 & 50.0 \\
$\quad$ RM1000 & 248 & 27.1 \\
RM1000 - RM1999 & 59 & 8.8 \\
RM2000 - RM2999 & 21 & 3.1 \\
RM3000 - RM3999 & 6 & 0.9 \\
Z RM4000 & & \\
Focus of work & 215 & 32.2 \\
Full time & 453 & 67.8 \\
Part time & & \\
Educational levels & 480 & 71.9 \\
Completed primary school & 159 & 23.8 \\
Completed secondary school & 22 & 3.3 \\
Certificate & 4 & 0.6 \\
Diploma & 3 & 0.4 \\
Bachelor/degree & & \\
\hline
\end{tabular}

\section{Crop profiles}

The findings from the study, according to Table 2, revealed the highest number of the farmers, 507 $(75.9 \%)$, started their cocoa plantation under programs facilitated by extension agents of the Malaysian Cocoa Board (MCB) in the 3 regions from the years 2006 - 2010. More than half of the farmers, 396 $(59.3 \%)$, used 3 - 5 clones for their cocoa plantation out of the clones presented to them by MCB extension agents. In the same way, $340(50.9 \%)$ of the cocoa farmers cultivated 1 - 3 hectares of cocoa farm land, while $316(47.3 \%)$ cultivated less than, or equal to, 1 hectare of cocoa farm land. The descriptive analysis of the source of information on cocoa technology by the respondents indicated that $51.4 \%$ received information from MCB extension agents, $21.3 \%$ of the farmers received information through their friends, and $10.8 \%$ received information on cocoa technologies from their families. 
Table 2 Crop profiles.

\begin{tabular}{lcc}
\hline Variables & Frequency & Percentage \\
\hline Location of office & 124 & \\
Hilir Perak & 100 & 18.6 \\
Machang & 129 & 15.0 \\
Jengka & 33 & 19.3 \\
Tawau & 67 & 4.9 \\
Tenom & 39 & 10.0 \\
Ranau & 47 & 5.8 \\
Keningau & 95 & 7.0 \\
Kota Samarahan & 34 & 14.4 \\
Betong & & 5.0 \\
Year started planting cocoa & 73 & \\
At/before 2000 & 88 & 10.9 \\
2001 - 2005 & 507 & 13.2 \\
2006 - 2010 & & 75.9 \\
Number of clones planted & 229 & \\
< Clones & 396 & 34.3 \\
3 - 5 Clones & 43 & 59.3 \\
25 Clones & & 6.4 \\
Hectares cultivated & 316 & 47.3 \\
< 1 Hectare & 340 & 50.9 \\
1 - 3 Hectares & 10 & 1.5 \\
3.1 - 5 Hectares & 2 & 0.3 \\
5.1 - 7 Hectares & & \\
Information on cocoa technology & 643 & 51.4 \\
MCB extension officers & 135 & 10.8 \\
Family & 267 & 21.3 \\
Friends & 44 & 3.5 \\
Pamphlet & 13 & 1.0 \\
Radio & 66 & 5.3 \\
Television & 46 & 3.7 \\
Newspaper & 28 & 2.2 \\
Internet & 9 & 0.7 \\
Others & &
\end{tabular}

Level of work performance

The descriptive statistics of the work performance of extension agents among cocoa farmers are presented in Table 3. The mean scores and standard deviations of the level of agreement were determined based on the range of $(1-2.669)$ as low, $(2.67-4.339)$ as moderate, and $(4.34-6.00)$ as high as indications of measurement for the levels on a 6-point scale of 6.00. From Table 3, the level of work performance was high $(\mathrm{M}=4.68 ; \mathrm{SD}=0.643)$.

Table 3 Level of work performance.

\begin{tabular}{lcc}
\hline Level & Mean & SD \\
\hline Work performance & 4.68 & 0.643 \\
\hline
\end{tabular}


Levels of leadership skill, decision making support skill, and social skill

The descriptive statistics of the contributions of leadership skill, decision making support skill, and social skill of extension agents among cocoa farmers are presented in Table 4. The mean scores and standard deviations of the level of agreement were determined based on the range of $(1-2.669)$ as low, (2.67 - 4.339) as moderate, and (4.34 - 6.00) as high as indications of measurement for the levels on a 6-point scale of 6.00. As indicated in Table 4, the mean scores ranged from 4.54 to 4.72, and the standard deviation also ranged from 6.34 to 0.696. From Table 4, all the factors that contributed to work performance showed high mean scores, with leadership skill $(\mathrm{M}=4.72$; $\mathrm{SD}=0.639)$ being the highest score, followed by decision making support skill $(\mathrm{M}=4.61$; $\mathrm{SD}=0.634)$; meanwhile, the lowest was social skill $(\mathrm{M}=4.54 ; \mathrm{SD}=0.696)$.

Table 4 Levels of leadership skill, decision making support skill, and social skill.

\begin{tabular}{lcc}
\hline Levels & Mean & SD \\
\hline Leadership skill & 4.72 & 0.639 \\
Decision making support skill & 4.61 & 0.634 \\
Social skill & 4.54 & 0.696 \\
\hline
\end{tabular}

\section{Influence of leadership skill, decision making support skill, and social skill on work performance}

The relationships between leadership skill, decision making support skill, and social skill and work performance were determined using Pearson correlation coefficients. Exploratory analysis was carried out to ensure non-violation of normality and linearity assumption. Bivariate correlation analysis results showed that all the skills were significant and correlated. As shown in Table 5, the relationship between decision making support skill and work performance was the strongest and, at same time, had a linear relationship $(r=0.683 ; p<0.01)$. The results also showed significant and positive correlation between social skill and work performance $(r=0.662 ; p<0.01)$ and between leadership skill and work performance $(r=0.660 ; p<0.01)$. Based on the findings of the study, hypotheses $\mathrm{H} 1, \mathrm{H} 2$, and $\mathrm{H} 3$ were supported, and reject null hypothesis.

Table 5 Bivariate correlation coefficients among leadership skill, decision making support skill, and social skill and work performance

\begin{tabular}{|c|c|c|c|c|c|}
\hline & Variables & WP & $\mathbf{L S}$ & DS & SS \\
\hline $\mathbf{W P}$ & Work performance & 1 & & & \\
\hline $\mathbf{L S}$ & Leadership skill & $0.660 * *$ & 1 & & \\
\hline DS & Decision making support skill & $0.683 * *$ & 0.681 & 1 & \\
\hline SS & Social skill & $0.662 * *$ & 0.681 & 708 & 1 \\
\hline
\end{tabular}

$* *$ Significant at $p<0.01$ level.

Effect of human resource development skills on work performance among cocoa farmers

In order to identify the effect of the skills on work performance, Table 6 presents the results of the regression analysis, based on the contribution of all independent variables to work performance. The 3 independent variables were supported and were statistically significant; the results showed that decision making support skill $(\beta=0.321 ; p<0.01)$ was the most important contributing factor that explained work performance compared to leadership skill $(\beta=0.270 ; p<0.01)$ and social skill $(\beta=0.251 ; p<0.01)$. 
$\mathrm{H} 1, \mathrm{H} 2$, and H3 were supported, as they were positive and significantly contributed to work performance. The summary statistics of the regression analysis show the variables for which the coefficients are statistically significant with $R^{2}$ of 0.564 . Work performances were attributed to the three dimensions of human resource development, with a combined contribution of $56.4 \%$ to variance of work performance. Hence, the results indicated that hypotheses $\mathrm{H} 4$ was supported and reject null hypothesis.

Table 6 Linear multiple regression of leadership skill, decision making support skill, and social skill and work performance.

\begin{tabular}{|c|c|c|c|c|c|}
\hline & \multicolumn{2}{|c|}{ Unstandardized coefficients } & \multicolumn{3}{|c|}{ Standardized coefficients } \\
\hline Skills & B & Std. error & Beta & $\mathbf{t}$ & Sig. \\
\hline Constant & 0.937 & 0.129 & & 7.243 & 0.000 \\
\hline Leadership skill & 0.251 & 0.035 & 0.270 & 7.131 & 0.000 \\
\hline Decision making support skill & 0.326 & 0.040 & 0.321 & 8.174 & 0.000 \\
\hline Social skill & 0.232 & 0.036 & 0.251 & 6.391 & 0.000 \\
\hline
\end{tabular}

Significant; ${ }^{* *} p<0.01, R=0.751, R^{2}=0.564$, Adj. $R^{2}=0.562$, Std. Error of the estimate $=0.42613$, $\beta=$ standardized regression coefficient, $t$ value $=$ test statistics of $\beta$.

The results revealed that there were significant associations between HRD skills (leadership skill, decision making support skill, and social skill) and work performance. They indicated that acquiring the right skill in human resource development will assist extension agents in developing the potential and capability of farmers towards the adoption and application of cocoa technology available to them for improved performance.

The earlier proposed hypotheses in the study was that leadership skill, decision making support skill, and social skill will influence work performance, and that they might act together to predict higher levels of work performance. The hypotheses were supported. The results for all 3 dimensions of human resource development were consistent with past research [36], [58], [59], in which it was also found that extension agent work performance is influenced by leadership skill, decision making support skill, and social skill.

Also, the results were supported by Sail [15] and Motolani et al. [16]; they reported the need for extension agents to be equipped with knowledge and skills in human resource development through regular training programs, as it will enhance effectiveness for higher performance in their work. Mengal and Habib [60] opined that unproductive human resource development activities within organizations would not only affect extension agent working patterns and practices, but also be responsible for delay in their operational processes and impede performance. According to Okwoche and Asogwa [36], Mbega [61], for any organization to be effective, there is the need for effective leadership; the neglect of this leadership aspect and approach will lead to poor individual and organizational performance. Furthermore, there is a general belief that, for any set of people or group to be effective, the quality and approach of their leaders matter most. This was confirmed by Tham-Agyekum [38]; the exhibited behavior of any leader goes a long way to positively affect outcomes in an effective and efficient manner, as well as facilitating the desires of followers that results in effective performance.

The results of the regression analysis, revealed in Table 6, indicated that the 3 variables influenced and contributed significantly to work performance. The model indicated the significance of the 3 skills, with $p<0.05$. Decision making support skills had the highest Beta value, at 0.321 . The $R^{2}$ value of 0.564 implies that the 3 predictors explained about $56.4 \%$ of the variation in extension agents' work 
performance. This was confirmed by Al-Zahrani [62], in which decision making support skill was the most effective skill to establish a good relationship with the performance of extension agents, as it strengthened the agricultural extension service and helped farmers to make sustainable production practice decisions on their farms.

\section{Policy implications and conclusion}

The limitation of this study emanated from the usage of the sample, meant to be representative of the whole population. Even though there is positive relationship between the dependent and independent variables, the work performance variance of $56.4 \%$ gives an explanation of the 3 significant independent variables. The use of productive cocoa farmers also serves as a limitation in this study, due to the fact that it may not be a representative sample of other cocoa farmers who are not involved in extension agentfacilitated programs. There is a need for more diverse samples for future research. The implications of the findings from this study focus on the need to integrate identifying skills that contribute to work performance into extension activities and human resource development programs to improve the skills of extension agents on the transfer of new technology among cocoa farmers. Much of the transference of cocoa-related technology by the extension agents lacked the required skills for effective delivery, such as leadership skill, decision making support skill, and social skill. Given the importance of the required skills for technology transfer, as well as the capacity and potential development of extension agents and cocoa farmers, these three skills should be entrenched in training programs introduced by agricultural extension service agencies in Malaysia, especially the Malaysian Cocoa Board, to enhance sustainable cocoa production.

The findings of the present study provide valuable information to extension and advisory services on work performance through human resource development, to develop both extension agents and clients' capacity and potential, which are the key factors in ensuring effectiveness of extension services to attain desired levels of performance. In practice, transferring technology to farmers by competent and skillful extension agents is very important to enable an improved standard of living and productivity. The study is significant to extension agents, as it highlights the necessary skills to be acquired for the effective delivery of any technology to their clients. In addition, this study contributes to better understanding of extension agents' work performance through cocoa growers, in which extension agents have a greater role to play; it will help them towards using knowledge and skills to develop cocoa farmers' capabilities and potential to increase their productivity by using the right techniques and skills for the technology available to them. Furthermore, research needs to be conducted from the perspective of extension agents on the adoption of technology transferred to cocoa farmers through effective use of human resource development skills and the role played by farmers, specifically in the aspect of adopting technology.

\section{Acknowledgements}

The authors would like to express their sincere gratitude to all cocoa farmers in the study area for their consent, valuable time, and positive responses during questionnaire administrations. We are also thankful for the support received from the Malaysian Cocoa Board during data collection.

\section{References}

[1] ICCO, Available at: https://www.icco.org/faq/57, accessed February 2018.

[2] KP Ramle. 2012, Contribution of group dynamics factors to technology adoption among Malaysia cocoa clusters, Ph.D. Dissertation. Universiti Putra Malaysia, Selangor, Malaysia.

[3] FM Arshad and A Ibragimov. Malaysia's cocoa beans decline: A prognosis. Int. J. Agr. Forest. Plantation 2015; 1, 1-14.

[4] L Wood. A study of Malaysia's cocoa industry: Malaysia cocoa industry report 2017. Available at: https://www.businesswire.com/news/home/20170503005811/en/Malaysia-Cocoa-Industry-Report2017---Research, accessed July 2018. 
[5] CH Lee. Planting cocoa-challenges and realities. Available at: http://www.ipicex.com/doc1/2012/ onral/PlantingCocoa-ChallengesandRealityinMalaysia.pdf, accessed September 2018.

[6] WR Fadzim, MIA Aziz and AZA Jalil. Determinants of technical efficiency of cocoa farmers in Malaysia. Int. J. Supply Chain Manag. 2017; 6, 254-8.

[7] MCB, Available at: http://www.koko.gov.my/lkm/industry/statistic/cocoacultivated.cfm, accessed May 2020.

[8] RM Sail. 2008, Kompetensi dan amalan pendidikan pengembangan (concept and practice of extension education). Buletin Pengembangan (Extension Bulletin). Bil.1. Universiti Putra Malaysia, Selangor, Malaysia.

[9] JM Saleh and NB Man. Training requirements of agricultural extension officers using Borich needs assessment model. J. Agr. Food Inform. 2017; 18, 110-22.

[10] A Issahaku. Perceived competencies of agriculture extension workers in extension services delivery in Northern region of Ghana, perspective from literature. Develop. Countr. Stud. 2014; 4, 107-15.

[11] N Tiraieyari, K Idris, J Uli and A Hamzah. Competencies influencing extension workers' job performance in relation to the good agricultural practices in Malaysia. Am. J. Appl. Sci. 2010; 7 , 1379-86.

[12] BN Wasihun, JA Kwarteng and EL Okorley. Professional and technical competencies of extension agents as perceived by male and female farmers and the extension agents themselves: The need for data source triangulation. J. Agr. Biodivers. Res. 2013; 2, 11-6.

[13] EM Zwane. The role of extension as a profession is critical in delivering excellent services: An experience from Limpopo, South Africa. J. Agr. Sci. 2014; 6, 1-7.

[14] M Suvedi and R Ghimire. How competent are agricultural extension agents and extension educators in Nepal? Available at: https://innovate.cired.vt.edu/wp-content/uploads/2015/ 09/SuvediNepalExtensionFINAL.pdf, accessed January 2019.

[15] RM Sail. Human resources development and transfer of technologies and their relationship to extension agents' job performance. Akademika 2010; 79, 127-37.

[16] MM Motolani, S Hassan, O Olagunju and K Ramle. ToT and HRD competencies and its relationship to extension agents' performance among cocoa smallholders. IOSR J. Agr. Vet. Sci. 2017; 10, 14-21.

[17] T Ayalew and T Abebe. Agricultural knowledge and technology transfer systems in the Southern Ethiopia. African J. Agr. Res. 2018; 13, 682-90.

[18] AU Ofuoku. Influence of extension agents' and farmers' communications factors on the effectiveness poultry technology messages. Trop. Agr. Res. Ext. 2013; 15, 14-23.

[19] AC Mcharo. 2013, Perception of farmers on effectiveness of agricultural extension agents in knowledge transfer to maize growers in Kilindi district. Ph.D. dissertation. Sokoine University of Agriculture, Morogoro, Tanzania.

[20] Texas A\&M University System. Texas A\&M AgriLife extension service county extension agent performance appraisal instrument. Texas Cooperative Extension Program, Texas, 2015.

[21] SH Chae, YD Kim and HJ Lim. Analysis of the association between competence and performancefocusing on farmers and extension workers. Am. J. Agr. Biol. Sci. 2014; 9, 101-8.

[22] GS Becker. Human capital: A theoretical and empirical analysis, with special reference to education. National Bureau of Economic Research, Cambridge, 1964.

[23] JM Unger, A Rauch, M Frese and N Rosenbusch. Human capital entrepreneurial success: A personal-analytical review. J. Bus. Ventur. 2011; 26, 341-58.

[24] R Zarutskie. The role of top management team human capital in venture capital markets: Evidence from first-time funds. J. Bus. Ventur. 2010; 25, 155-72.

[25] MA Mamabolo. 2016, Human capital investments and skills outcomes specific to the different entrepreneurship phases. Ph.D. Dissertation. University of Pretoria, Pretoria, South Africa.

[26] D Ucbasaran, P Westhead and M Wright. Opportunity identification and pursuit: Does an entrepreneur's human capital matter. Small Bus. Econ. 2008; 30, 153-73.

[27] MS Cardon, DA Gregoire, CE Stevens and PC Patel. Measuring entrepreneurial passion: Conceptual foundations and scale validation. J. Bus. Ventur. 2013; 28, 373-96. 
[28] G Feder, JR Anderson, R Birner and K Deininger. Promises and realities of community-based agricultural extension. In: K Otsuka and K Kaliraja (Eds.). Community, market and state in development. Palgrave Macmillan, London, 2010, p. 187-208.

[29] K Davis, E Nkonya, E Kato, DA Mekonnen, M Odendo, R Miiro and J Nkuba. Impact of farmer field schools on agricultural productivity and poverty in East Africa. World Dev. 2012; 40, 402-13.

[30] WM Rivera, MK. Qamar and LV Crowder. Agricultural and rural extension worldwide: Options for institutional reform in the developing countries. J. Int. Agr. Ext. Educ. 2001; 15, 19-31.

[31] MA Bodla and MM Nawaz. Comparative study of full range leadership model among faculty members in public and private sector higher education institutes and universities. Int. J. Bus. Manag. 2010; 5, 208-14.

[32] M Rizwan, MN Khan, B Nadeem and Q Abbas. The impact of workforce diversity towards employee performance: Evidence from banking sector of Pakistan. Am. J. Market. Res. 2016; 2, 5360.

[33] MV Gravina. 2013, Investigating leadership characteristics and attitudes toward creativity according to agency context for agriculture extension agents in Uruguay. Ph.D. Dissertation. Oklahoma State University, Oklahoma, USA.

[34] R Karami and M Ismail. Achievement motivation in the leadership role of extension agents. Cambridge Scholars Publishing, Newcastle upon Tyne, 2014, p. 1-14.

[35] O Khalil, A Hassan, M Ismail, T Suandi, and AD Silong. Extension worker as a leader to farmers: Influence of extension leadership competencies and organizational commitment on extension workers' performance in Yemen. J. Int. Soc. Res. 2008; 1, 370-87.

[36] VA Okwoche and BC Asogwa. Analysis of determinants of job performance of agricultural extension worker as a leader to farmers in Nigeria. Br. J. Econ. Finance Manag. Sci. 2012; 5, 1-21.

[37] MW Luvanda. 2015, Factors affecting the job performance of agricultural extension workers in Handeni district, Tanzania. Ph.D. Dissertation. Sokoine University of Agriculture, Morogoro, Tanzania.

[38] EK Tham-Agyekum. A review of the application of leadership principles in agricultural extension in Ghana Available at: https:/www.academia.edu/24812942/A_REVIEW_OF_THE_ APPLICATION_OF_LEADERSHIP_PRINCIPLES_IN_AGRICULTURAL_EXTENSIŌN_ IN_GHANA, accessed April 2018.

[39] G Steptoe-Warren, D Howat and I Hume. Strategic thinking and decision making: Literature review. J. Strat. Manag. 2011; 4, 238-50.

[40] MK Singh, D Ram, K Sanatombi and A Prasad. Correlates training needs assessment of assistant agriculture officers of Manipur. Indian Res. J. Ext. Educ. 2011; 11, 120-1.

[41] HK Kalita. Training need of village level extension workers of hills zone of Assam. J. Acad. Ind. Res. 2014; 3, 98-100.

[42] P Das and S Borua. Socio-economic characteristics of ATMA (Agricultural Technology Management Agency) extension functionaries in Assam and their relationship to their training needs. Asian J. Agr. Ext. Econ. Sociol. 2017; 16, 1-5.

[43] N Tiraieyari. 2009, Relationships between extension workers' competencies and job performance in implementing the good agricultural practices programme in Malaysia. Ph.D. Dissertation. Universiti Putra Malaysia, Selangor, Malaysia.

[44] WA Hochwarter, LA Witt, DC Treadway and GR Ferris. The interaction of social skill and organizational support on job performance. J. Appl. Psychol. 2006; 91, 482-9.

[45] Y Wu. 2008, Social skill in the workplace: What is social skill and how does it matter. Ph.D. Dissertation. University of Missouri, Missouri, USA.

[46] M Beheshtifar and T Norozy. Social skills: A factor to employees'success. Int. J. Acad. Res. Bus. Soc. Sci. 2013; 3, 74-9.

[47] T Okumura and E Usui. Do parents' social skills influence their children's sociability? B.E. J. Econ. Anal. Pol. 2015; 14, 1-36.

[48] JA Odumeru and OA Ilesanmi. The effects of human resources development on financial performance of organisations. Asian Bus. Rev. 2015; 2, 19-23. 
[49] T Sitzmann and K Ely. A meta-analysis of self-regulated learning in work-related training and educational attainment: What we know and where we need to go. Psychol. Bull. 2011; 137, 421-42.

[50] DE Gberevbie. Impact of human resource development and organizational commitment on financial sector employees in Nigeria. Ann. Alexandru Ioan Cuza Univ. Econ. 2012; 59, 29-41.

[51] AM Gidado, S Kusairi and S Muhamad. Investing in human resource development: Empirical evidence from banking institutions of Malaysia and Nigeria. J. Econ. Sustain. Dev. 2014; 5, 123-33.

[52] BO Akinyemi. Human Resource Development Climate (HRDC) in the banking sector: General and gender perceptions. Int. J. Bus. Manag. 2014; 9, 77-86.

[53] M Hamid, S Maheen, A Cheem and R Yaseen. Impact of human resource management on organizational performance. J. Account. Market. 2017; 6, 1-7.

[54] MCB. Available at: http://www.koko.gov.my/lkm/industry/statistic/cocoacultivated.com, accessed March 2019.

[55] RV Krejcie and DW Morgan. Determining sample size for research activities. Educ. Psychol. Meas. 1970; 30, 607-10.

[56] E Babbie. The practice of social research. Wardsworth Cengage Learning Center, Asia, 2015.

[57] SA Adesoji, M Famakinwa and AE Eghosa. Assessment of agricultural extension students' interest in providing private extension services in Nigeria. Assess. J. Agr. Sci. Sri Lanka 2019; 14, 57-66.

[58] $\mathrm{N}$ Tiraieyari and $\mathrm{J}$ Uli. The moderating role of age groups on the relationship between social competencies and work performance. Afr. J. Agr. Res. 2011; 6, 3660-4.

[59] D Bortamuly. 2015, A Study on the role performance of the agricultural extension personnel in the revitalized extension system in the State of Assam. Ph.D. Dissertation. Assam Agricultural University, Jorhat, India.

[60] AA Mengal and S Habib. Human resource development for an effective agriculture extension tool: An empirical study of Baluchistan province. Int. J. Agr. Ext. 2016; 4, 71-7.

[61] WL Mbega. 2015, Factors affecting the job performance of agricultural extension workers in Handeni district, Tanzania. Master Thesis. University of Agriculture, Morogoro, Tanzania.

[62] KH Al-Zahrani, FO Aldosari, MB Baig, MY Shalaby and GS Straquadine. Role of agricultural extension service in creating decision making environment for the farmers to realize sustainable agriculture in Al-Qassim and Al-Kharj regions - Saudi Arabia. J. Anim. Plant Sci. 2016; 26, 106371 . 